\title{
LIGGER SKAERSILDEN PÅ VEJEN FRA BYEN TIL HIMLEN?
}

\section{Om by og religion i Jacques Le Goffs mentalitetshistoriske syntese af Middelalderen}

\author{
Af Ole Bay
}

\section{Annales-skolen}

Mentalitetshistorie er gennem de sidste år blevet et centralt område i historieskrivningen - ikke blot i udlandet, men også i Danmark, som blandt andet flere numre af Den Jyske Historiker vidner om. ${ }^{1}$

Nok den væsentligste inspirationskilde har været fransk historieskrivning - særligt den tradition, der er knyttet til tidsskriftet Annales. Economies. Sociétés. Civilisations. Tidsskriftet blev grundlagt i 1929 af Lucien Febvre og Marc Bloch. Det var fra begyndelsen præget af en tydelig front mod en traditionel historieskrivning, som man anklagede for at koncentrere sig om enkeltbegivenheder, fordi den afviste de krav om en systematisk, generaliserende samfundsvidenskab, der i Frankrig særlig var blevet rejst fra sociologisk side. Tidsskriftets oprindelige sigte var at skabe rammen om en empirisk baseret diskussion af økonomiens problemer, hvor man blandt andet var inspireret af den økonomiske socio$\log$ François Simiands fors $\emptyset \mathrm{g}$ på at skabe en $\emptyset$ konomisk videnskab, der baserede sig på omfattende empiriske unders $\emptyset$ gelser og ikke på teoretiske modeller. Men der var også en tydelig interesse for det, vi nu vil kalde mentalitetshistoriske problemstillinger. Særlig Marc Bloch var klart inspireret af den franske sociolog Émile Durkheim, der så sociologiens hovedemne i den kollektive mentalitet, der var årsagen til samfundets sammenhængskraft. Durkheim afviste, at individualpsykologiske problemer kunne behandles videnskabeligt, og hos ham ligger derfor en af rødderne til den manglende interesse for det individuelle plan og for begivenheder, der har præget Annales-skolen. Marc Blochs store og i samtiden stort set oversete værk Les Rois Thaumaturges (1924), hvori han undersøgte udviklingen af de franske og engelske kongers undergørende kræfter, kan opfattes som et fors $\emptyset \mathrm{g}$ på at skabe en formidling 


\section{Skærsilden}

mellem synspunkterne $\mathrm{i}$ den traditionelle historievidenskab og $\mathrm{i}$ den durkheimske sociologi. ${ }^{2}$ I 1970'erne blev denne bog af mange, også Jacques Le Goff, fremhævet som et forbilledligt værk for en historisk antropologi. ${ }^{3}$ Marc Blochs senere produktion, særlig La société féodale (1939-40), får dog en tydelig vægt på den kollektive mentalitet og sociale strukturer, medens enkeltbegivenheder og individuelle mennesker næsten fuldstændig forsvinder.

I de første efterkrigsår, hvor Annales-traditionen blev etableret som den dominerende retning i Frankrig, blandt andet ved oprettelsen af den forskeruddannelsesinstitution, der i dag er École des Hautes Études en Science Sociale, var de typiske disputatser omfattende sociale og økonomiske undersøgelser med hovedvægt på de forhold, som ændrede sig langsomt, næsten umærkeligt. Det paradigmatiske arbejde var Fernand Braudels La Méditerranée et le monde mediterranéen à l'époque de Philippe II fra 1947, der med sin gennemførte etageopdeling med et afsnit om strukturer, ét om konjunkturer - de lange bølger - og ét om begivenhederne klart skilte begivenhederne ud som skum på konjunkturernes bølger. Selv om Braudel anvendte begrebet struktur, skilte han det skarpt fra det ahistoriske strukturbegreb, de franske strukturalister som f.eks. Claude Lévi-Strauss anvendte. For Braudel var historiske strukturer altid under udvikling, selv om det foregik umærkeligt for de enkelte mennesker, der levede i udviklingen.

Da Braudel forlod redaktionen for Annales, skete der imidlertid et markant skift mod mentalitetshistorien, hvor indflydelsen fra strukturalismen blev tydelig.

I mentalitetshistorien fik religionen en central plads, først og fremmest i middelalderhistorien. Her er Jacques Le Goff en væsentlig skikkelse, ikke mindst på grund af hans La naissance du Purgatoire (1981), der er blevet fremhævet som et mønstereksempel for den ny mentalitetshistorie.

\section{Jacques Le Goff}

Jacques Le Goff har længe haft en central position i fransk historievidenskab, både som medlem af redaktionskomitéen for Annales. Économies. Sociétés. Civilisations, som redaktør af de to store samleværker, der gjorde status for den »ny « franske historie i 1970'erne, ${ }^{4}$ og som directeur dés études ved École des Hautes Études en Sciences Sociales. 
Det er altid vanskeligt at vurdere en videnskabelig produktion, der strækker sig over små 30 år, som en helhed. Der vil være synspunkter, der er nogenlunde konstante, og andre, der forandrer sig. Det er her min opfattelse, at det billede af Middelalderen, Jacques Le Goff viste i sine tidlige arbejder, stadig er den ramme, han forstår Middelalderen i, men at han har udviklet en interesse for specielt nogle emner i denne middelalder og en metodisk og teoretisk forfinelse.

Le Goffs videnskabelige produktion viser en lidt unormal udviklingslinie. Hans første væsentlige arbejder var synteseprægede. Der er tale om først to bøger, der behandlede de to socialgrupper, der er forblevet centrale i hans historiske interesse - Les intellectuels au Moyen Age (1957) og Marchands et banquiers du Moyen Age (1956) - og derefter om to synteser, der dækkede store dele af middelalderen - La civilisation de l'Occident médiéval (1964) og Das Hochmittelalter (1965). I dag vurderer han stadig La civilisation de l'Occident médiéval og Les intellectuels au Moyen Age som centrale værker. Men derefter bestod hans produktion i mange år af spredte artikler - så spredte, at mange først fik et overblik over dem ved udgivelsen af artikelsamlingerne Pour une autre Moyen Age (1977) og L'Imaginaire Médiéval (1985). La naissance de la Purgatoire blev derfor Le Goffs første egentlige bog i mange år.

Jacques Le Goff har selv sagt, at hans væentligste inspiratorer har været den franske historiker Fernand Braudel, marxismen og den franske strukturalisme. ${ }^{5}$

Hans tidlige arbejder er præget af en stærkt sociologiserende tendens. Han betegner selv sin skitse af de intellektuelle i Middelalderen som en sociologisk undersøgelse, og den middelalderhistoriker, han dengang oftest påberåbte sig, var Marc Bloch, og vel at mærke dennes sene, meget sociologiserende arbejde La Société Féodale. Det er nok muligt bag interessen for sociale strukturer at ane en marxistisk inspiration. Strukturen i den første del af hans Das Hochmittelalter er baseret på at beskrive først den økonomiske udvikling og derefter udviklingen på andre områder: sociale, politiske og religiøse, der alle opfattes som betinget af den økonomiske udvikling.

Om La civilisation de l'Occident médiéval har han selv senere påpeget, at dispositionen er præget af en marxistisk inspireret fremstillingsteknik ved at gå fra det simple til det komplekse, ${ }^{6}$ men Le Goff følger også en niveau-delt fremstilling, som ligner Braudels, men lægger et andet ind- 


\section{Skærsilden}

hold i den. F.eks. har både La Méditerranée et le monde méditerranéen à l'époque de Philippe II og La civilisation de l'Occident médiéval afsnit om tid og rum. Men Braudel beskrev de fysiske afstande, de fysiske tider. Le Goff beskriver, hvorledes datidens mennesker oplevede afstande og tider. De to efterfølgende kapitler lægger sig op ad Braudels struktur: Der er ét om vie matérielle og ét om samfundet, men det næste kapitel handler ikke om begivenheder, men om mentalitet, sensibilitet og følelser. Forskellen mellem Le Goffs og Braudels tilgang viste sig også tydeligt, da de i 1974 begge skrev et afsnit til den store Storia d'Italia fra forlaget Einaudi. Begge afsnit havde hovedtitlen Italien uden for Italien, men hvor Fernand Braudel diskuterede handel og økonomiske konjunkturer, beskrev Le Goff billedet af Italien, som man så det i datiden. ${ }^{7}$

\section{Indflydelsen fra strukturalismen}

Påvirkningen fra den tredje hovedindflydelse, Lévi-Strauss og med ham den franske strukturalisme, bliver først tydelig i Le Goffs arbejder fra begyndelsen af 1970'erne. Den generation af historikere, han tilhørte, søgte efter Fernand Braudels afgang fra redaktionen af Annales at prioritere en strukturalistisk inspireret mentalitetshistorie højere, og Le Goff søgte selv i flere artikler fra denne tid at påvise anvendeligheden af strukturalistiske metoder.

Jacques Le Goff har argumenteret for en ny kildeopfattelse, der udtrykker en nyvurdering af forholdet mellem monument og dokument. I fransk historieskrivning har document været begrebet for kilden, men Jacques Le Goff ønsker i stedet kilden udnyttet som monument, dvs. som et skabt mindesmærke, der udtrykker ophavssituationens magtstruktur. Dokumentet var ikke uskyldigt: Det udtrykker fortidens samfunds magt over erindringen og fremtiden: dokumentet er et monument. ${ }^{8}$ Selv om skellet monument/document minder om sondringen mellem beretning og levning, som man i dansk historievidenskab har kendt den siden Kr. Erslev, ${ }^{9}$ er der væesentlige forskelle. Medens Erslev mente, at kilderne ofte samtidigt kunne tolkes som beretninger om fortiden og som levninger af fortidige handlinger, dvs. at man fra kilden kunne slutte tilbage til ophavssituationen, er Jacques Le Goff ikke så meget interesseret $\mathrm{i}$ at slutte til en bagvedliggende virkelighed, til ophavssituationen, som i den meningsstruktur, kilden er en del af. F.eks. er Middelalderens mange forfalskninger naturligvis som beretninger værdiløse, men vurderet som 
levninger kan de sige meget om datidens virkelighedsopfattelse, der gjorde forfalskningerne sande for en senere generation. ${ }^{10}$

Le Goff skelner mellem memoire som den skabte erindring om fortiden, som forfalskningen er skabt til at være en sand del af, og den (videnskabelige) histoire, der kan undersøge erindringen som udtryk for magten, ${ }^{11}$ og derfor kan vurdere f.eks. forfalskningen som monument. I skellet mellem dokument og monument støtter han sig direkte på Michel Foucault, og det er Foucaults altomfattende magtbegreb, hvor magten også udtrykkes i diskursen, han refererer til. ${ }^{12}$ Strukturalismen hjælper forskeren til at likvidere en falsk »historisme«, der søger at finde konkrete historiske begivenheder bag eventyr og legender. ${ }^{13}$ Det er den manglende interesse for begivenhedshistorien, der gør, at Le Goff fuldstændig vil afvise beretningsudnyttelsen af kilden. I stedet $\emptyset$ nsker han en total historie, der som emne arbejder med globaliserende objekter som f.eks. fattigdommen, marginaliteten etc., ${ }^{14}$ altså undersøger sociale praktikker, pratiques, i den Foucaultske term. ${ }^{15}$ Hvor man før søgte at finde de reelle sociale forhold bag fortællinger, myter m.m., lægger Le Goff i sine mere teoretiske udtalelser vægt på, at repræsentationerne har deres egen historie og deres egen logik, og at de ikke kun udtrykker sociale forhold, men også selv påvirker udviklingen. Et typisk eksempel er den måde, hvorpå han undersøger geografiske forestillinger, hvad enten de er om det kendte Vesteuropa, om det halvmytiske Indiske Ocean eller om Skærsilden.

Strukturalismen giver Le Goff grundlaget for, at mentalitetshistorien kan tillægges en relativ selvstændighed $\mathrm{i}$ forhold til den mere materialistiske forståelsesramme. Her kan han vende sig mod marxismen, som han anser for den eneste reelle historieteori fra det 19. århundrede, men hvis basis-overbygningsmodel og evolutionisme eller endda eskatologi han anser som forfejlet og derfor som en del af den dogmatiske marxisme, han afviser. ${ }^{16}$

Historievidenskabens opgave bliver at afvise determinismen, afvise afmagten og ligegyldigheden og påvise, at intet er forudbestemt, og at mennesket kan ændre de forhold, der er skabt om det. ${ }^{17}$ Le Goff understreger, at troen på Skærsilden er opstået inden for et system, som kun giver mening $\mathrm{i}$ forhold til dets funktion $\mathrm{i}$ et totalt samfund - selv om det ikke er bestemt af dette. ${ }^{18}$

Som metode til analyse kan Le Goff anvende en strukturalistisk læs- 


\section{Skærsilden}

ning, hvor han henviser til Lévi-Strauss. Men det er dog kun undtagelsesvis, han har anvendt denne metode. Derimod har han ofte støttet sig på Propps Eventyrets morfologi og på det store materiale af folkelige fortællinger, der er indsamlet især i det 19. århundrede, og som er tematiseret af Stith-Thompson. Han tør støtte sig på dette materiale, fordi han mener, at der ved siden af den lærde (savante) kultur er en folkelig kultur, der er præget af meget stor kontinuitet. Det ser han dokumenteret derved, at temaerne i folkelige fortællinger, der er nedskrevet i Middelalderen, genfindes i de temaoversigter, der er udarbejdet over de langt senere nedskrevne folkeeventyr. ${ }^{19}$ Han argumenterer ikke for, hvorfor dette fællesskab i mytisk bevidsthed eksisterer - i modsætning til f.eks. Georges Dumézil, der har set en fælles indo-europæisk oprindelse som forudsætning for sine religionshistoriske resultater, og Carlo Ginzburg, der har antydet en fælles indoeuropæisk-finsk-ugrisk rod for sin teori om en oprindelig frugtbarhedskult, hvis spredte rester blev forfulgt under de store hekseforfølgelser. ${ }^{20}$

Le Goff er klar over den kritik, der er blevet rejst af f.eks. Peter Brown over for opdelingen i disse to kulturniveauer, men Brown kritiserer teorien om en konstant eller næsten ubevægelig, uforfinet folkelig religiøsitet. ${ }^{21}$ En noget tilsvarende model findes hos den russiske historiker A. Ja. Gurevitch, i hvis undersøgelser af middelalderlig folkelig religiøsitet hovedvægten synes at ligge på den relativt ringe påvirkning fra den lærde kultur. ${ }^{22}$ Derimod ser Le Goff ikke det folkelige niveau som konstant eller kun under pres fra den lærde kultur, men ser en stadig gensidig påvirkning mellem de to lag. Det er blandt andet i dét perspektiv, at han opfatter $» \sin$ « Middelalder som en meget lang Middelalder, der strækker sig fra Romerrigets opløsning og helt frem til det 19. århundrede. For Le Goff er det ikke den materielle civilisation, men det mentale univers, der har den trægeste udviklingstakt. Denne Middelalder er præget af den dominerende ideologi, der hverken ud fra et materialistisk synspunkt kan betragtes som en refleks af basis eller ud fra en idealistisk som historiens motor. Kristendommen betragter han både som religion og som ideologi, og den både understøtter og anfægter det feudale samfund. ${ }^{23}$ Ideologi opfatter han som en verdensforståelse, der ikke naivt reflekterer virkeligheden, men bliver skabt for at styre menneskers handlinger. ${ }^{24}$ Hvad han definerer som religionens specifikke område, er mere uklart. 


\section{Byen i Middelalderen}

For Jacques Le Goff er Middelalderen domineret økonomisk og socialt af landområderne. Bøndernes produktion var den afgørende del af produktionen, og adelen, der normalt boede på landet, var den dominerende klasse. Bøndernes situation er sørgelig: Le Goff understreger ligheden med ulandene, den stærke undertrykkelse og den foragt, bønderne blev behandlet med. Det var ikke tilfældigt, at begrebet hedning (paganus) havde rod i ordet for landbo, og det var heller ikke tilfældigt, at ingen bønder blev helgenkåret i Middelalderen. Købmænd og pengeudlånere spillede en minimal rolle $\mathrm{i}$ forhold til landet: bønderne, adelen og gejstligheden var de afgørende sociale grupper. I den tidlige Middelalder frem til det 10. århundrede var der en skarp konflikt mellem kristne og hedenske normer, hvor de hedenske sås som knyttet til bønderne. ${ }^{25}$ Eperne og den høviske kultur bliver, når de slår igennem den klerikale kultur, et udtryk for feudalismens triumf ${ }^{26} \mathrm{og}$ for, at den kristne religion er så etableret, at den ikke længere ser konflikten med den folkelige kultur som en religiøs konflikt. ${ }^{27}$

På trods af, at han kun tillægger byerne en mindre rolle, er næsten hele Le Goffs produktion koncentreret omkring byerne og de spændinger i samfundet, deres udvikling medførte. Det centrale er spændingen mellem en traditionalistisk, rural eller måske endda civilisationsfjendtlig kirke over for byerne med deres nye værdisæt, som det giver sig udtryk både $\mathrm{i}$ universiteterne og i købmændenes etiske problemer.

Både byernes vakst fra det 11. århundrede og deres nedgang fra det 14. århundrede skyldtes efter Le Goffs mening udviklingen i den rurale sektor - først væksten under den store nyopdyrkningstid fra ca. år 1000 og siden nedgangen efter den senmiddelalderlige agrarkrise. Selv om byerne var integreret $\mathrm{i}$ det feudale system, og byernes overklasser stod sammen med adelen under sociale konflikter, var byernes overklasse dog baseret på et andet værdisæt end adelen. Rigdom var penge og ikke jord, hierarkiet var horisontalt og ikke vertikalt, arbejde og ikke lediggang var en dyd, den økonomiske kalkule erstattede den systematiske gavmildhed. ${ }^{28}$ Selv om samfundet ikke var kapitalistisk efter strikte marxistiske begreber, var de store købmænd det i kraft af deres tænkemåde, deres livsform og deres plads i samfundet. ${ }^{29}$

Medens byen i Senmiddelalderen mister både sin relative politiske selvstændighed og en stor del af sin økonomiske betydning, forbliver den 


\section{Skærsillden}

stadig et kulturelt selvstændigt område med andre normer, en egen mental struktur.

En meget vigtig del af Jacques Le Goffs arbejde drejer sig netop om Kirkens reaktion over for byerne med deres nye normer og nye behov for idémæssig retfærdiggørelse. Reaktionerne viser sig i nye institutioner, som universiteterne og tiggerbrødreordnerne, der oprindelig behandles med mistænksomhed af den traditionelle kirke, både fordi de står for en anderledes mentalitet, og fordi der i kanten af dem optræder grupper, der er klart i opposition til de traditionelle autoriteter. Og reaktionen ses i ændringer i Kirkens dogmer, som det kommer frem i tidsbegrebet, i forholdet til arbejde, til ågervirksomhed og til syndsbegrebet i sin helhed. Her bliver Skærsilden et samlende udtryk for den udvikling, Kirkens doktrin gennemgår.

Kirken var traditionelt bundet til aristokratiets normer, og selv om det bevarede erindringen om det mere positive forhold til arbejde, der lå i den jødisk-kristne tradition, blev arbejdet i den tidlige middelalder opfattet som en straf. Allerede under den karolingiske tid og særlig kraftigt under den store nyopdyrkningstid i det 11 . århundrede sker der en ændring i denne opfattelse. Mennesket ses nu som skabende, ligesom Gud var skabende, og det skabende arbejde får en værdi i sig selv. ${ }^{30}$

Allerede i sin skoletid gik det op for Jacques Le Goff, hvor vigtigt tidsbegrebet var. Han fik et chok, da han hørte, at man have søgt at ændre kalenderen under Den franske Revolution. ${ }^{31}$ Og indførelsen af Revolutionskalenderen var netop vendt mod Kirkens kontrol med kalenderen. I et par tidlige arbejder har Le Goff behandlet det nye tidsbegreb, der opstod med byerne. Han stillede den mekanisk målte tid op over for den rurale og aristokratiske tid, der var bundet til årstidernes skiften og vejret. For $k \emptyset b m a n d e n$, for arbejdsgiveren og særlig for pengeudlåneren bliver tiden nu noget, der skal måles, og udbredelsen af de mekaniske ure foregår netop i byerne. Deroverfor så religionen tiden i eskatologiens perspektiv. ${ }^{32} \mathrm{Nu}$ er den ny tidsmåling imidlertid nært knyttet til Kirken. Urene sad oftest på kirker, og Lewis Mumford har fremsat den, i dag dog ikke helt uanfægtede teori, at det netop var det kirkelige behov for at tjene Herren på de rette tidspunkter, f.eks. ved midnat, der gjorde urene nødvendige. ${ }^{33}$ Det er først væsentligt senere, at den mekanisk målte tid bliver det, der bestemmer arbejstiden. ${ }^{34}$ Le Goff har selv senere fremhævet borgernes klokketårn, der gav mulighed for 
at kalde borgerne sammen på uregelmæssige tidspunkter efter behov og slå arbejstidens begyndelse og ophør, som et klarere udtryk for byens selvfølelse over for Kirkens klokke, der slog de regelmæssige gudstjenestetider. ${ }^{35}$

Behandlingen af tidsbegrebet viser igen, hvorledes Jacques Le Goffs mentalitetshistoriske tilgang skiller ham fra Fernand Braudels materialistiske. Braudel havde i artiklen La longue durée fra 1958 argumenteret for, at der sameksisterede forskellige tidsbegreber $\mathrm{i}$ den historiske udvikling: Man kunne tale om ét tidsbegreb knyttet til individet, til begivenhedsplanet, et andet til sociale konjunkturer og et tredje til de materielle strukturer. For Braudel var strukturer ikke evige, men udviklede sig i historien. Heroverfor er Jacques Le Goffs tidsbegreb knyttet til den oplevede tid, og kun indirekte til den reelt fungerende tid. Tidsbegrebet er knyttet til sociale grupper eller sociale situationer og fungerer gennem deres mentalitet. Ågerkarlen kunne - om end med nogen utryghed - leve både med den beregnelige rentetid og den noget mere uberegnelige ende på det timelige, som Kirken repræsenterede. ${ }^{36}$ Selv ser Jacques Le Goff oprindelsen til flerheden af sociale tider hos både Fernand Braudel og ham selv $\mathrm{i}$ den franske durkheimsociolog Maurice Halbwachs Les Cadres sociaux de la mémoire (1925), hvor individet oplever tidsbegrebet netop som hos Le Goff gennem de normer, der hører til en bestemt social gruppe. ${ }^{37}$ Når Le Goff i dag arbejder på en biografi over den franske konge Louis XI (1226-1270), der senere blev kanoniseret som Saint Louis (Ludvig den Hellige), og dermed koncentrerer sig om et individ, er det blandt andet fordi biografien viser le temps vécu, den gennemlevede eller oplevede tid. ${ }^{38}$ Braudel derimod, der i meget af sit arbejde havde haft Philip II i horisonten, mente nok, at han kunne skrive en livsskildring på et par uger, men en sådan ville blot være litteratur; en egentlig videnskabelig bearbejdning var for vanskelig. ${ }^{39}$

\section{Kirkens rolle}

Købmændenes virksomhed fordømtes officielt af Kirken, da handel ikke var arbejde. Særlig hårdt fordømtes pengeudlån, da det man solgte for renter, var tiden, som hørte Gud til. Men den kommercielle revolution og Pavedømmets eget behov for likvide midler, særlig efter den gregorianske reform $\mathrm{i}$ det 11 . århundrede, gjorde, at Kirken ikke blot accep- 


\section{Skærsilden}

terede, men endda indirekte selv deltog i udlånsvirksomhed.

Det, Jacques Le Goff med et tydeligt anakronistisk udtryk betegner som de intellektuelle, er en klart afgrænset gruppe, der vokser frem sammen med universiteterne, der som lærdomssæder i modsætning til klostrene, som før var centrum for kirkens uddannelse, var snævert knyttet til byerne. Skolastikken, der fremstår med universiteterne, bliver derfor særlig følsom over for bylivets problemer. Af den traditionelle kirke blev de intellektuelle klandret, fordi de sælger viden, altså sandhed, og også Sandheden hører kun Gud til. Skolastikkens senere stagnation ser Le Goff som en parallel til den aristokratisering og dermed sociale afgrænsning, der prægede universiteterne i Senmiddelalderen, hvor byerne også befandt sig i økonomisk stagnation.

En anden del af Kirkens tilpasning til byfænomenet bliver tiggermunkene, som ligesom de intellektuelle er i delvis opposition til den etablerede kirke. I modsætning til de traditionelle munkeordner, der søgte at skabe en landlig isolation som forudsætning for deres elitære fromhedsliv, lå brødrenes klostre i byerne, og de var forpligtet til at virke udadvendt mod byernes liv. Skønt der var tydelige træk af afstandtagen fra byernes materialisme, var brødreordnerne samtidigt gennem deres prædikener vendt mod byernes særlige problemer og viser dér en langt større forståelse for den ny by end den traditionelle teologi. Det er derfor Jacques Le Goff har undersøgt tiggerbrødrenes samlinger af opbyggelige fortællinger, exempla, for at se, hvorledes Kirken i sin forkyndelse reagerede på byfænomenet.

Le Goff er meget opmærksom på de marginale grupper. Det gælder de af de frie sintellektuelle - goliarderne - der tilsyneladende helt brød ud af de religiøse rammer. Og det gælder kætterne, der ved at gå til angreb på Kirken gik til angreb på samfundets ideologiske fundament ligesom de også gjorde det ved at ændre på Kirkens eskatologi og dermed dens kontrol med tidsbegrebet; ${ }^{40}$ derfor er de periodens virkelige revolutionære. ${ }^{41}$ For Le Goff er kætterbevægelserne en reaktion mod fremskridtet, mod den $\emptyset$ konomiske vækst. De er et mindretal, der protesterer ud fra en følelse af social uretfærdighed, ${ }^{42}$ hvorimod den etablerede religion $\mathrm{i}$ det 13 . århundrede, der står $\mathrm{i}$ den sociale stabiliserings tegn, forsøger at fordømme ønsket om at bryde ud af sin egen stand. ${ }^{43}$ Tiggerbrødreordnerne, særlig franciskanerne, har længe efter deres oprettelse spor af utilfredshed med den etablerede kirke og særlig dens 
rigdom i sig. ${ }^{44}$ Og endnu tydeligere viser en urovækkende fromhed sig i senmiddelalderlige lægmandsbevægelser som Beguinerne, som Le Goffs elev Jean-Claude Schmitt har beskrevet i sin bog fra 1978, og de såkaldte $»$ Brødre og søstre af den frie ånd «.

Det er typisk for Jacques Le Goff, at gotikkens fremvækst falder sammen med byernes og kongemagtens vækst, selv om han er klar over, at man ikke kan sætte lighedstegn mellem romansk arkitektur og klostercivilisationen. ${ }^{45}$ Georges Duby har derimod netop peget på gotikkens oprindelse i Citeaux i Sankt Bernhards teologi, der på så mange måder ellers vendte sig mod byen og alt det nye, den stod for. ${ }^{46}$ At de store gotiske katedraler blev bygget $\mathrm{i}$ byerne, var naturligvis et udtryk for byernes voksende rigdom, men også nødvendigt, fordi katedralerne som bispekirker skulle ligge i stiftsstæderne. Kirken havde jo med stædig institutionel konservatisme bevaret en principielt bybaseret organisation og erindringen om den antikke bykultur.

I religionen ser Jacques Le Goff Kirkens reaktion i den individualisering og opblødning af reaktionen på synder. Hvor skriftefædrene før brugte pønitentialer, håndbøger, der viste den faste straf for hver enkelt synd, bliver skriftefædrenes vejledninger nu rettesnore i individuel vejledning. Man ser mere på synderen end på synden, og der sker en stadig mere individuel stillingtagen til fordømmmelige erhverv. ${ }^{47}$ Synderne bliver målelige og vejelige - svarende til byernes nye normer - og Skærsilden, der netop indfører en beregnelighed af det hinsides, svarer fuldstændigt til den udvikling.

\section{Skærsilden}

Det er med disse referencerammer, at Le Goff skriver bogen om Skærsildens fødsel.

Bogen søger at forklare, hvorfor troen på Skærsilden bliver en central del af den latinske kristenheds religion netop omkring 1250. Skærsilden som den rensende ild findes som et grundtema i indoeuropæisk mytologi, og langt tilbage i den kristne doktrinudvikling kan man se rødderne til Skarsilden, men Jacques Le Goff mener ikke, at troen på Skærsilden fulgte uundgåeligt af de kristne dogmer og andre trosforestillinger. En arv foreslår, den kræver ikke. Tværtimod synes de dogmatiske kilder gennem lang tid ikke at vise nogen udvikling af skærsildsbegrebet. Og selv om den omtales, har denne rensende ild ikke nogen central plads i 


\section{Skarsilden}

de kristne læresætninger. Derimod kan man følge skærsildsbegrebets udvikling gennem beretninger om rejser $\mathrm{i}$ det hinsides. Det er et kildemateriale, der stærkere end de dogmatiske kilder præges af presset fra den folkelige kultur og fra før-kristne forestillinger om det hinsides, som man stadig ser dem f.eks. hos Saxo. Oprindelig er der kun tale om en rensende ild, der placeres upræcist $\mathrm{i}$ tid og rum i det hinsides. Her er der tegn, der peger mod en mellemproportional mellem Helvede og Himlen, på en mellemvej mellem de frelste og fordømte, men det forbliver længe ved antydningen. Tilsyneladende er han ikke opmærksom på, at Propp har set rejsen - der har en struktur, der enten består af kampen mod modstanderen og sejren over ham eller den vanskelige opgave og løsningen af den - som en grundstruktur i eventyrene, der er en refleks af den religiøse ide om sjælenes rejse i det hinsides. ${ }^{48}$

Efterhånden ses en udvikling, hvor Skærsilden får en mere og mere præcis placering. Den bliver indplaceret som et sted, adskilt fra Helvede og Himmel, og med en beliggenhed, der ikke er på jorden, men nok kan nås fysisk fra jorden, og som en straf, der placeres før adgangen til Himlen, $\mathrm{i}$ en nøje udmålt tid og måde. Der er ikke noget substantiv for begrebet $f ø r$ det 13 . århundrede.

I modsætning til en traditionel ånds- eller dogmehistorisk fremstilling, hvor skærsildsbegrebet kunne ses som en logisk nødvendig følge af tidligere standpunkter, er den første del af bogen på sin vis en ikkehistorie, fordi den kun beskriver Skærsildens mulighed og dens ikkeudvikling, hvor udviklingsmulighederne kun antydes at ligge i området mellem den officielle teologi og den folkelige mentalitet.

Når Jacques Le Goff skal forklare, hvorfor Skærsilden får sit gennembrud i bevidstheden $\mathrm{i}$ det 13 . århundrede, kan han pege på flere årsager. Skærsilden støtter sig som sagt på gamle forestilllinger om ildens rensende kraft, og Le Goff ser i denne periode flere tegn på, at denne gamle arv presser sig igennem til den officielle ideologi. Den høviske kultur, der netop trænger frem i denne periode, og som støtter sig på den eneste kultur uden for Kirkens fulde kontrol, den folkelige, betragter han som en modkultur til Kirkens. ${ }^{49}$ Et andet udtryk er den tredelte samfundsopfattelse, hvor samfundet ses som bestående af tre grupper: én der kæmper, én der beder, og én der arbejder. Men han kan ikke passe denne funktionelle tredeling sammen med skærsildstroens konsolidering. Han ser det væsentlige i overgangen fra den 
binære verdensopfattelse til den ternære, og her lægger han i stedet vægt på tredelingen som en inddeling i tre grader. Skærsilden bliver netop et tredje sted mellem Himmel og Helvede - og det bliver stedet for en tredje slags mennesker - mellemgruppen, der hverken er helt gode eller helt onde, og derfor skal til et sted midt imellem. Derfor lægger Le Goff mere vægt på opdelingen af samfundet i majores, mediocres et minores i det 13. århundrede end på den funktionelle tredeling.

Jacques Le Goff var en af de første historikere, der søgte at anvende den tredeling i magt-, krigs- og frugtbarhedsguder, Georges Dumézil havde fundet næsten overalt $\mathrm{i}$ den indoeuropæiske verden, ${ }^{50}$ på Middelalderhistorien, hvor man finder den samme tredeling $\mathrm{i}$ den tredelte standsopfattelse, der viser sig i det 11. århundrede. Oprindeligt opfattede Le Goff det væesentligste heri som anerkendelsen af den tredje, arbejdende stand ved siden af de to herskende klasser, gejstligheden og adelen. Det skulle direkte udtrykke betydningen af de entrepenante bønder, der netop da var gået $\mathrm{i}$ gang med at bryde ny jord op. ${ }^{51}$ Han kan derfor se tredelingsmotivets fremtrængen som en del af det pres fra den folkelige kultur, som den høviske kultur også er udtryk for. Et forsøg på at opdele byen topografisk på de tre funktioner ${ }^{52}$ virker ikke overbevisende. I den Saint Louis-biografi, han er i gang med at skrive, søger han at strukturere fremstillingen af kongens virke på de tre funktionsområder ${ }^{53}$ I La naissance du Purgatoire har Jacques Le Goff både brug for tredelingen, fordi den jo netop kommer til at svare nøje til den tredeling i det hinsides, som bliver konstrueret med Himmel-SkærsildHelvede, men mere for en gradueret tredeling, der ville svare til syndernes grovhed, end en funktionel, som den netop findes hos Dumézil. Som Georges Duby har vist, er der faktisk langt tidligere tredelinger efter fromhed - munk-præst-verdslig - længe før tredelingen af det hinsides blev aktuel. ${ }^{54}$

Vigtigere er imidlertid de store sociale ændringer, der sker på den tid. Der findes tidlige spor af Skærsilden i de exempla, der blev brugt i tiggerbrødrenes prædikener, der netop primært var vendt mod byerne. Skærsildstroens egentlige gennembrud foregår i sammenkoblingen af bymiljø med den lærde klostertradition og hænger nært sammen med den opblomstring af teologien, der viser sig i skolastikken. Endelig får Skærsilden betydning i kampen mod kætteriet. Det 13. århundrede er også de oprindelige »kættere«, katharernes, periode. Fordi han ser 


\section{Skærsilden}

Skærsildens udvikling i meget nær tilknytning til den sociale udvikling i byerne, er det magtpåliggende for Le Goff at understrege, at han ikke mener, at bourgoisiet har skabt Skærsilden, eller at den på en eller anden måde afhænger af bourgoisiets udvikling. Hans hypotese er, at Skærsilden er en del af, et element i, den mentalitetsændring, der er en del af den transformation, det feudale Europa undergår.

\section{Konklusion}

Som styrken og svagheden ved Le Goffs store historiske arbejde må man først og fremmest se viljen til at skabe sammenhænge. Uanset om hans konklusioner ikke $\mathrm{i}$ alle områder er helt overbevisende, har han peget på væsentlige mulige sammenhænge mellem den sociale og økonomiske udvikling og den kollektive mentalitet.

Den kombination af interesse for mentalitetshistorie med et relativt materialistisk historiesyn, som er tydelig hos Jacques Le Goff, kan føres tilbage til Annales-skolens første tid.

Braudel havde et grundlæggende materialistisk (om end mere prokapitalistisk end marxistisk) historiesyn. Men den tendens, Le Goff stod for, repræsenterede også Annales-skolen. Splittetheden finder man tydeligt hos Lucien Febvre. Han havde som Fernand Braudel på mange måder et massivt materialistisk historiesyn, men selv om han opererede med et tidvis deterministisk historiesyn, var hans hovedinteresse det enkelte menneskes muligheder for at tænke og opleve verden, som han viste det $\mathrm{i}$ en række meget omhyggelige og bevidst meget nuancerede undersøgelser af, præcist hvordan en række personer kunne forholde sig til religionen på reformationstiden.

Som det måske var endnu tydeligere hos den anden af Annales-skolens grundlæggere, Marc Bloch, betød særlig indflydelsen fra Émile Durkheim, at religionen kunne tillægges den centrale betydning i samfundet.

Selv om Le Goff teoretisk med støtte i strukturalismen argumenterer for mentalitetshistoriens selvstændighed, befinder hans forklaringer sig dog hele tiden inden for rammerne af en materialistisk historieforståelse, hvor den sociale sammenhæng er det dynamiske element, som mentaliteten med større eller mindre træghed tilpasser sig, uden at mentalitetens indhold dog blot er en simpel refleks af den sociale virkelighed. Men det bliver ikke udviklingen af mentaliteten, der skaber den 
$\emptyset$ konomiske og sociale udvikling. Jacques Le Goff har aldrig som Marc Bloch antydet, at religionens betydning for den økonomiske udvikling er større end omvendt.

\section{Litteratur}

Bay, Ole, "The evolution of the historical thought of Marc Bloch«, Tijdschrift voor theoretische geschiedenis, Jaarg. 15, 1988, 148-162.

Bisgaard, Lars, »Adelen og »de syv dødelige synder«. Omkring kalkmalerierne i Bollerup Kirke«, Kongemagt og Samfund i Middelalderen. Festskrift til Erik Ulsig, red. Poul Enemark, Jens Villiam Jensen og Per Ingesman, Århus 1987, 287-305.

Bisgaard, Lars, Tjenesteideal og fromhedsideal. Studier $i$ adelens toenkemåde $i$ dansk senmiddelalder, Ånus 1988.

Braudel, Fernand, »Histoire et sciences sociales. La longue durée«, artikel fra 1958, genoptrykt i Fernand Braudel, Écrits sur l'histoire, Paris 1969, 41-83.

Braudel, Fernand, »L'Italia fuori d'Italia. Due secoli e tre Italie«, (Einaudi) Storia d'Italia, Volume secondo: Dalla caduta dell'Impero romano al secolo XVIII, Torino 1974, 2092-2248.

Braudel, Fernand, I tempi della storia. Economie, società, civiltà, Bari 1986.

Bremond, Claude; Jacques Le Goff; Jean-Claude Schmitt, L'xexemplum«, Turnhout 1982.

Brown, Peter, The Cult of the Saints, London 1983 (orig. 1981).

Duby, Georges, Les trois ordres ou l'imaginaire du féodalisme, Paris 1978.

Duby, Georges, Saint Bernard. L'art cistercien, Paris 1979 (orig. 1976).

Duby, Georges, The Age of the Cathedrals. Art and Society 980-1420, Chicago 1981.

Erslev, Kr., Historisk Teknik. Den historiske Unders $\emptyset$ gelse fremstillet $i$ sine Grundlinier, København 1972 (orig. 1912).

Forcellini, Paolo, »Salig er kapitalen«, Weekendavisen, den 11.2.1988 (Interview med Jacques Le Goff).

Foucault, Michel, The Archaeology of Knowledge, London 1972 (orig. 1969).

Gimpel, Jean, The Medieval Machine, London 1979 (orig. 1976).

Ginzburg, Carlo, „Sabbatens natur«, Häxornas Europa 1400-1700, red. Bengt Ankarloo och Gustav Henningsen, Lund 1987, 113-126. 


\section{Skærsilden}

Gurevitch, A. Ja., »Popular and scholarly medieval cultural traditions. Notes in the margin of Jacques Le Goff's book «, Journal of Medieval History 9, 1983, 71-90.

Gurevitch, A. Ja., Les catégories de la culture médiévale, Paris 1983(a).

Gurevitch, A. Ja., "Tiden som kulturhistorisk problem«, Kultur \& Klasse, 48, 1983(b), 90-110.

Gurevitch, A. Ja., Mittelalterliche Volkskultur, München 1987.

Halbwachs, Maurice, Les Cadres sociaux de la mémoire, Paris 1935 (orig. 1925).

Johnson, Douglas, „The Twentieth Century: Recollection and Rejection «, The Permanent Revolution. The French Revolution and its Legacy, ed. Geoffrey Best, London 1988.

Le Goff, Jacques, Marchands et banquiers du Moyen Age, Paris 1956.

Le Goff, Jacques, Les intellectuels au Moyen Age, Paris 1957 (Den italienske udgave er benyttet: Gli intelletuali nel Medievo, Milano 1985).

Le Goff, Jacques, La civilisation de l'Occident médiéval, Paris 1977 (orig. 1964).

Le Goff, Jacques, Das Hochmittelalter, Fischer Weltgeschichte, Band 11, Frankfurt a.M 1977 (orig. 1965).

Le Goff, Jacques, "The Town as an Agent of Civilisation«, The Fontana Economic History of Europe, Vol. 1: The Middle Ages, London 1972, 71107.

Le Goff, Jacques, "L'Italia fuori d'Italia. L'Italia nello specchio del Medievo«, (Einaudi) Storia d'Italia, Volume secondo: Dalla caduta dell'Impero romano al secolo XVIII, Torino 1974(a), 1935-2088.

Le Goff, Jacques, "Les mentalités : une histoire ambiguë«, i Le Goff og Nora 1974, 107-129 (citeret som Le Goff 1974 b).

Le Goff, Jacques, Pour une autre Moyen Age, Paris 1977.

Le Goff, Jacques (red.), La nouvelle histoire, Paris 1978(a).

Le Goff, Jacques, »L'histoire nouvelle«, i Le Goff 1978a, 210-241 (citeret som Le Goff 1978b).

Le Goff, Jacques, »Une science en marche, une science dans l'enfance«, i Le Goff 1978a, 11-20 (citeret som Le Goff 1978c).

Le Goff, Jacques, "L'apogée de la France urbaine médiévale 11501330«, Histoire de la France urbaine, Tome 2: La ville médiévale des Carolingiens à la Renaissance, Paris 1980.

Le Goff, Jacques, La naissance du Purgatoire, Paris 1981. 
Le Goff, Jacques, Intervista sulla storia, A cura di Francesco Maiello, Roma-Bari 1982.

Le Goff, Jacques, »Préface«, i Marc Bloch, Les Rois Thaumaturges, Paris 1983, I-XXXVIII.

Le Goff, Jacques, L'imaginaire médiéval, Paris 1985.

Le Goff, Jacques, La bourse et la vie, Paris 1986(a).

Le Goff, Jacques, Storia e memoria, Torino 1986(b).

Le Goff, Jacques, "After Annales: The Life as history«, Times Literary Supplement April 14-20 1989, 394 og 405.

Le Goff, Jacques, Pierre Nora, Faire de l'histoire, I-III, Paris 1986 (orig. 1974).

Propp, V. Ja., Eventyrets morfologi, uddrag i Torben Krag Grodahl o.a., udg., Tekststrukturer, København 1974.

Schjødt, Jens Peter, „Georges Dumézil og indoeuropæisk religionshistorie «, Religionsvidenskabeligt Tidsskrift, 5, 1984, 5-35.

Schmitt, Jean-Claude, Mort d'une hérésie. L'Église et les clercs face aux béguines et aux béghards du Rhin supérieur du XIVe au XVe siècle, Paris 1978.

Thompson, E. P., »Time, Work-Discipline and Industrial Capitalism«, Past \& Present 38, 1967, 56-97.

Zerlang, Martin, »Problemer og perspektiver i fransk mentalitetshistorie«, Kultur \& Klasse, 48, 1983, 8-29.

\section{Noter}

1. F.eks. Den jyske Historiker nr. 26: Fejekosten og surdejen (1983) og nr. 29-30: Kultur, mentalitet, ideologi (1984). Mentalitetshistorien er blevet præsenteret i Kultur \& Klasse nr. 48: Mentalitetshistorie (1983). Lars Bisgaards arbejder er direkte inspireret af Le Goff.

2. Bay $1988,153 \mathrm{f}$.

3. Le Goff 1986b, 116; Le Goff 1983.

4. Le Goff 1978a; Le Goff og Nora 1974.

5. Le Goff $1977,9$.

6. Le Goff 1982, 108.

7. Braudel 1974; Le Goff 1974a.

8. Le Goff 1986b, XI.

9. Erslev 1972, 75.

10. Le Goff $1982,98$.

11. Le Goff 1986b, $117 \mathrm{ff}, 397 \mathrm{ff}$.

12. Foucault 1972, 6 ff; Le Goff 1986b, 449 ff.

13. Le Goff 1977, 326; Le Goff 1978b, 238. 


\section{Skærsilden}

14. Le Goff $1986 b, 32$.

15. Le Goff 1986b, 88.

16. Le Goff $1986 \mathrm{~b}, 80 \mathrm{ff}, 297$.

17. Le Goff 1986b, 129.

18. Le Goff $1986 \mathrm{~b}, 32$.

19. Le Goff 1984, $40 \mathrm{ff}$.

20. Ginzburg 1987, 121.

21. Brown 1983, $20 \mathrm{ff}$.

22. Gurevitch 1987, 14, 29. Transskriptionsproblemer gør, at forfatteren i de tyske udgaver staves Gurjewitsch og i de franske Gourevitch.

23. Le Goff $1985,8 \mathrm{f}$.

24. Le Goff 1985 , III.

25. Le Goff 1964, 147; Le Goff 1977, $224 \mathrm{ff}$.

26. Le Goff $1965,176$.

27. Jf. Le Goff 1977, 276.

28. Le Goff $1980,244$.

29. Le Goff $1956,41$.

30. Le Goff 1977, 96, 124.

31. Johnson 1988, 202.

32. Le Goff 1977, 56; Le Goff 1986b, $286 \mathrm{ff}$.

33. Gimpel 1979, 142.

34. Thompson 1967.

35. Le Goff $1980,269,368$.

36. Le Goff 1986 .

37. Halbwachs $1935,376 \mathrm{f}$.

38. Le Goff 1989, 405. Han synes altså foreløbelig at have opgivet sin undersøgelse af en i hans øjne væsentligt mere magtfuld $\mathrm{og}$ i religionshistorisk perspektiv måske mere interessant person, nemlig Satan selv (jf. Le Goff 1985, XVIII).

39. Braudel 1986, 85, 115.

40. Le Goff $1977,50$.

41. Le Goff $1965,182$.

42. Le Goff 1965, 186; Le Goff 1977, 165.

43. Le Goff 1965, 218.

44. Le Goff $1965,254$.

45. Le Goff $1965,172$.

46. Duby 1976, $147 \mathrm{ff}$; Duby 1981, $97 \mathrm{ff}$.

47. Le Goff $1977,162 \mathrm{ff}$.

48. Ginzburg 1987, 122.

49. Le Goff $1977,162 \mathrm{ff}$.

50. Jf. Schjødt, 1984.

51. Le Goff $1977,86 \mathrm{f}$.

52. Le Goff 1980, $224 \mathrm{ff}$.

53. Le Goff 1989, 405.

54. Duby 1978, $105 \mathrm{ff}$. 


\section{Ole Bay}

\section{Summary}

"The Birth of Purgatory. Towns and Religion in the Christian Middle Ages, according to Jacques Le Goff and his History of Mentalities". - The article presents the work of the French historian Jacques Le Goff centered on his 1981 study on the birth of the Purgatory.

Though working within a largely marxist conception of class structure, his main interest has always been the history of mentalities, which he increasingly threats in an approach inspired by Michel Foucault.

His main interest has been the interaction of the development of the towns in the Middle Ages with the institutions of the Christian religion. The Purgatory, which represented an intermediate, measurable punishment between Heaven and Hell, he sees as a part of the Church's reaction to the new morality of the cities. It now gave hope for Salvation for increasingly prominent urban sins like usury by punishing it not by total damnation, but by a limited, though certainly painfully long, stay in Purgatory.

Ole Bay

Adjunkt, cand. mag.

VUC Skanderborg-Odder 